\title{
PENGGUNAAN MEDIA ALTERNATIVE (DIAPERS) TERHADAP PERTUMBUHAN DAN PRODUKSI TANAMAN CABAI
}

\author{
Safrizal $^{1}$, Nazimah ${ }^{1}$, Rina Ressi ${ }^{1}$ \\ Email Author: safrizalsarong@yahoo.com
}

\begin{abstract}
ABSTRAK
Cabai merah merupakan sayuran utama baik di Indonesia maupun di mancanegara karena memiliki banyak manfaat terhadap kebutuhan gizi dan kesehatan melalui bumbu masakan. Pemanfaatkan lahan pekarangan rumah merupakan cara efektif untuk budidaya tanaman cabai. Disisi lain, setiap rumah tangga menghasilkan limbah rumah tangga yang sulit terdekomposisi seperti diapers sehingga dalam waktu lama akan menyebabkan pencemaran lingkungan. Penelitian ini bertujuan untuk mengetahui peranan media tanam diapers limbah rumah tangga terhadap pertumbuhan cabai. Hasil penelitian menunjukkan bahwa penggunaan media tanam diapers limbah rumah tangga memberikan respon yang tidak berbeda nyata terhadap tinggi tanaman pada umur $1,4,7$, 10, 13 dan 16 MST, jumlah daun pada umur 1, 7, 10, 13 dan 16 MST, panjang daun pada umur 1, 4, 7, 10 dan 16 MST, lebar daun pada umur 1, 4, 7, 10, 13 dan 16 MST, dan jumlah cabang pada umur 1, 4, 7, 13 dan 16 MST. Namun memberikan respon yang berbeda nyata terhadap jumlah daun pada umur 4 MST, panjang daun pada umur 13 MST, Interaksi penggunaan media tanam diapers limbah rumah tangga memberikan respon berbeda nyata terhadap jumlah akar, panjang akar, berat basah akar dan tajuk tanaman, dan berat kering akar dan tajuk tanaman.
\end{abstract}

\section{Kata kunci: Media Tanam, Diapers, Tanaman Cabai}

\begin{abstract}
Red chili is a major vegetable both in Indonesia and abroad due to its benefits to the needs of nutrition and health through cooking spices. Utilization of home garden yard is an effective way to cultivate pepper plants. On the other hand, every household produces household waste which is difficult to decompose for instance diapers, so that it can cause environmental pollution in long-term. This study was conducted to investigate the role of planting media such as diapers of on chili growth. The results showed that the use of diapers of diapers as planting media gave no significant different to plant height at 1, 4, 7, 10, 13 and 16 week after application. It also did not increase the number of leaves at the age of 1,7,10,13 and 16 week after application. There were no changes in leaf length at ages 1, 4, 7, 10 and 16 week after application. It also happened to also its leaf width at ages 1, 4, 7, 10, 13 and 16 week after application and number of branches at ages 1, 4, 7, 13 and 16 week after aplication. However, it showed a significant different to the number of leaves at age 4 week after planting and its leaf length at age 13 week after planting. The interaction of using diapers as planting media gave significantly different response to root number, root length, wet root weight and plant canopy, and dry weight roots and plant canopy.
\end{abstract}

Keywords: Planting Media, Diapers, Chili Plants

\footnotetext{
${ }^{1}$ Program studi Agroekoteknologi Fakultas Pertanian Universitas Malikussaleh, Aceh Utara
} 


\section{PENDAHULUAN}

Indonesia merupakan negara agraris yang mayoritas penduduknya bermata pencaharian sebagai petani. Hal ini ditunjang dari banyaknya lahan kosong termasuk lahan pekarangan yang dapat dimanfaatkan sebagai lahan pertanian, dengan agroekosistem yang sangat mendukung seperti curah hujan, keadaan tanah dan cahaya matahari optimal, menyebabkan Indonesia menjadi salah satu negara produsen hortikultura khususnya cabai.

Salah satu produk olerikultura (sayur-sayuran) yang menjadi unggulan adalah termasuk cabai (Poerwanto, 2014). Cabai merah merupakan salah satu sayuran yang disukai baik di Indonesia maupun dimancanegara karena memiliki banyak manfaat terhadap kebutuhan gigi dan kesehatan. Cabai merah biasanya dipakai sebagai bumbu masak dan pelengkap masakan, juga dimanfaatkan dalam bidang campuran obat-obatan herbal (Wuryaningsih, 2008).

Produksi cabai segar pada tahun 2011 sebesar 888,852 ribu ton dengan luas panen sebesar 121,063 ribu hektar atau hanya mampu memenuhi 52\% kebutuhan cabai nasional (BPS, 2012). Sehingga perlu adanya ektensifikasi/peningkatan luas tanam terhadap komoditi cabai termasuk pemanfaatan lahan-lahan pekarangan potensial (Rukmana, 2003).

Memanfaatkan lahan disekitar pekarangan rumah penduduk untuk budidaya tanaman mengalami banyak kendala. Beberapa kendala tersebut yang paling berpengaruh signifikan adalah terhadap ketersediaan media tanam akibat kecenderungan lahan pekarangan merupakan tanah marginal, seperti aerasi yang kurang baik akibat kaedaan tanah yang terlalu padat, kandungan hara rendah, tidak sepenuhnya areal lahan pekarangan yang dapat ditanami akibat telah ternaungi oleh tanaman lainnya (Tjahjadi, 1991).

Disisi lain, Setiap rumah tangga akan menghasilkan limbah-limbah rumah tangga dengan jumlah dan jenis yang sangat bervariasi. Dari variasi tersebut ada yang bersifat biodegradable sehingga secara alamiah akan terdekomposisi dengan sempurna dan mampu menyuburkan tanah. Namun, banyak juga limbah rumah tangga yang bersifat sangat sulit terdekomposisi sehingga dalam waktu lama akan menyebabkan pencemaran lingkungan, seperti limbah diapers instan atau disposable diaper. Diapers adalah sejenis bahan popok sekali pakai berupa PEP yang memiliki sifat penyerap yang umumnya terbuat dari bahan penyerap seperti tissue, fluff, pulp serta berfungsi menyerap cairan hasil ekskresi padatubuh bayi seperti kencing dan kotoran padat. Diapers secara fenologimemiliki efek negative dimana sangat sukar melepaskan air yang telah terabsorbsi (Michael, 2002).

Berdasarkan hal diatas, maka diperlukan pemanfaatan lahan di sekeliling pekarangan rumah untuk budidaya hortikultura khususnya cabai dengan memodifikasi limbah rumah tangga yang bersifat nondegradable khususnya pampers bayi agar dapat dimanfaatkan sebagai media pertumbuhan dan produksi tanaman cabai merah dan cabai rawit.

\section{METODE PENELITIAN}

\section{Waktu dan Tempat Pelaksanaan}

Pelaksanaan penelitian dimulai dari bulan Juni sampai Desember 2016. Penelitian ini dilaksanakan di Desa Paloh Punti Kecamatan Muara Satu Kota 
Lhokseumawe ketinggian tempat 500 meter di atas permukaan laut (dpl)dan Laboratorium Agroekoteknologi Fakultas Pertanian Universitas Malikussaleh. Areal pekarangan berupa hamparan pekarangan dengan kriteria memiliki agroekosistem homogeny.

Bahan yang digunakan untuk penelitian yaitu tanaman cabai merah, cabai rawit, tanah, diapers, pupuk organik (pupuk kandang sapi), pupuk anorganik (pupuk NPK). Alat-alat yang digunakan yaitu cangkul, karung, galon air, penggaris, alat tulis, camera, open, dan timbangan analitik.

\section{Desain Percobaan}

Penelitian ini menggunakan Rancangan Acak Kelompok (RAK) pola faktorial dengan dua faktor yang diuji. Adapun kedua faktor tersebut adalah dua jenis tanaman cabai $\left(\mathrm{C}_{0}=\right.$ cabai merah dan $\mathrm{C}_{1}=$ cabai rawit) dan factor kedua komposisi media diapers $\left(\mathrm{P}_{0}=\right.$ tanpa diapers /kontrol, $\mathrm{P}_{1}=1 / 4$ diapers $+3 / 4$ media tanah, $\mathrm{P}_{2}=1 / 2$ diapers $+1 / 2$ media tanah, dan $\mathrm{P}_{3}=3 / 4$ diapers $+1 / 4$ media tanah.media dimasukkan dalam gallon agua bekas sebagai pengganti polybag. Sehingga terdapat 8 perlakuan dan masing-masing diulang 3 kali sehingga terdapat 24 satuan percobaan. Selain itu juga disediakan sampel destruktif untuk mengamati anatomi perakaran.

\section{Pelaksanaan Penelitian}

Lahan pekarangan yang digunakan sebagai lokasi penelitian dibersihkan, kemudian tanah diratakan dan dibuat petakan percobaan dengan ukuran $1.4 \mathrm{~m} \mathrm{x} 4.4 \mathrm{~m}$ sebagai tempat untuk meletakkan barisan media tanam yang telah dimasukkan dalam gallon air bekas. Jarak antar satuan percobaan 50 $\mathrm{cm}$ dan jarak antar kelompok masingmasing $100 \mathrm{~cm}$. Setelah itu, setiap satuan perlakuan diberi pupuk dasar berupa 150 gr/satuan. Pupuk dicampur merata dengan tanah dan dibiarkan selama seminggu dan selanjutnya dilakukan penanaman.

Variable yang diamati antara lain: tinggi tanaman, jumlah daun, panjang daun, leba daun, jumlah percabangan, umur berbunga, jumlah akar, panjang akar, berat segar tajukakar, dan berat kering akar-tajuk.

\section{HASIL DAN PEMBAHASAN}

Hasil analisis ragam menunjukkan tidak terjadi interaksi yang nyata antara perlakuan varietas cabai dan media diapers. Perlakuan varietas cabai berpengaruh sangat nyata terhadap tinggi tanaman pada umur 1, 4, 7, 10,13 dan 16 MST. Perlakuan media diapers tidak berpengaruh nyata terhadap tinggi tanaman pada umur 1, 4, 7, 10,13 dan 16 MST (Tabel 3). 
Tabel 3. Rerata Tinggi Tanaman (cm) Akibat Perlakuan Varietas Cabai dan Media Diapers

\begin{tabular}{lcccccc}
\hline \multirow{2}{*}{ Perlakuan } & \multicolumn{6}{c}{ Umur Tanaman (Minggu) } \\
\cline { 2 - 7 } C0P0 & 1 MST & 4 MST & 7 MST & 10 MST & 13 MST & 16 MST \\
\hline C0P1 & 11,333 a & 17,000 a & 25,867 a & 37,367 a & 41,700 a & 46,067 a \\
\hline C0P2 & 12,833 a & 16,267 a & 27,600 a & 31,533 a & 34,833 a & 38,333 a \\
\hline C0P3 & 11,700 a & 17,700 a & 22,900 a & 33,000 a & 37,733 a & 42,100 a \\
\hline C1P0 & 12,167 a & 17,700 a & 24,167 a & 30,467 a & 33,800 a & 40,833 a \\
\hline C1P1 & 12,200 a & 16,633 a & 25,767 a & 39,000 a & 44,867 a & 48,267 a \\
\hline C1P2 & 11,733 a & 17,733 a & 25,033 a & 32,767 a & 33,833 a & 35,467 a \\
\hline C1P3 & 13,667 a & 18,400 a & 25,033 a & 36,167 a & 40,900 a & 44,200 a \\
\hline
\end{tabular}

Keterangan : Angka yang didampingi huruf yang sama pada kolom yang sama dan peubah yang sama tidak berbeda nyata pada uji DMRT taraf $5 \%$.

Hasil penelitian menunjukkan bahwa perlakuan varietas cabai rawit dengan kombinasi $1 / 4$ media diapers $+3 / 4$ media tanah $\left(\mathrm{C}_{0} \mathrm{P}_{0}\right)$ menghasilkan tinggi tanaman yang lebih tinggi dan terendah dijumpai pada perlakuan varietas cabai besar dengan kombinasi kontrol atau tanpa diapers $\left(\mathrm{C}_{0} \mathrm{P}_{0}\right)$. Perlakuan varietas cabai rawit dengan kombinasi $1 / 2$ media diapers $+1 / 2$ media tanah $\left(\mathrm{C}_{1} \mathrm{P}_{2}\right)$ menghasilkan tinggi tanaman terendah. Secara statistik perlakuan kombinasi pampers tidak berpengaruh nyata terhadap tinggi tanaman, namun kondisi tanaman yang diberikan kombinasi diapers dilihat secara fisik untuk tanaman terlihat sangat nyata.

Tinggi tanaman yang terbaik terdapat pada perlakuan varietas cabai rawit dengan kombinasi $1 / 4$ media diapers $+3 / 4$ media tanah $\left(\mathrm{C}_{1} \mathrm{P}_{1}\right)$ Tanaman yang mendapatkan perlakuan kombinasi diapers yang lebih banyak maka lebih rendah pertumbuhan tinggi tanamannya, hal ini dikarenakan kondisi tanaman mengalami stres air yang berlebihan. Stres air dapat menyebabkan penghambatan aktivitas fotosintetis pada jaringan mesofil, serta penurunan aktivitas metabolik dan translokasi fotoasimilat.

Dampak dari berkurangnya fotosintesis pada pertumbuhan dan perkembangan tumbuhan khususnya tinggi tanaman sangat dramatis dan secara bersamaan dapat menyebabkan disfungsi fisiologis seperti penghambatan transportasi air dan perubahan keseimbangan hormon. Hal ini merupakan dampak dari sifat diapers yang memiliki sebagai bahan absorber paling efektif dengan kemampuan mengikat air pada unit-unit bahannya yang sangat kuat (Campbel,et.al;2007).

Terhadap jumlah daun cabai, hasil analisis ragam menunjukkan tidak terjadi interaksi nyata antara perlakuan varietas cabai dan media diapers. Hasil penelitian menunjukkan bahwa pada minggu 13 varietas cabai rawit dengan kombiasi tanpa kontrol atau tanpa media diapers $\left(\mathrm{C}_{1} \mathrm{P}_{0}\right)$ menghasilkan jumlah daun 174,33 helai, dan perlakuan varietas cabai rawit dengan kombinasi $3 / 4$ media diapers $+1 / 4$ media tanah $\left(\mathrm{C}_{0} \mathrm{P}_{3}\right)$ dan $1 / 4$ media diapers $+3 / 4$ media tanah $\left(\mathrm{C}_{1} \mathrm{P}_{3}\right)$ 
menghasilkan jumlah daun 140,00. Pada minngu 16 menunjukkan bahwa perlakuan cabai rawit dengan kombinsai $3 / 4$ media diapers $+1 / 4$ media tanah $\left(\mathrm{C}_{1} \mathrm{P}_{3}\right)$ masih mengalami peningkatan jumlah daun yang nyata, tetapi pada perlakuan yang lain mengalami penurunan jumlah daun yang sangat nyata. Jumlah daun yang terendah terdapat pada perlakuan varietas cabai rawit dengan kombinasi $1 / 2$ media diapers $+1 / 2$ media tanah $\left(\mathrm{C}_{1} \mathrm{P}_{2}\right)$. Nampaknya Flushing daun selain dikontrol oleh genetis juga dipengaruhi oleh kecukupan pembagian fotosintat khusus perbaikan maintnant pada tiap tahapan fotosintesis pada setiap daun normal yang dimiliki (Safrizal,2007), sehingga pada fase vegetative kemunculan daun baru dihasilkan duakali lipat dibanding fase generative (Poerwanto,2014).

Perlakuan varietas cabai berpengaruh sangat nyata terhadap jumlah daun tanaman pada umur 1, 4, 7, 10, 13 dan 16 MST. Perlakuan media diapers berpengaruh sangat nyata terhadap jumlah daun tanaman pada umur 1, 4, 7, 10, 13 dan 16 MST (Tabel 4).

Tabel 4. Rerata Jumlah Daun Tanaman (helai) Akibat Perlakuan Varietas Cabai dan Media Diapers.

\begin{tabular}{lllllll}
\hline \multirow{2}{*}{ Perlakuan } & \multicolumn{6}{c}{ Umur Tanaman (Minggu) } \\
\cline { 2 - 7 } & 1 MST & 4 MST & 7 MST & 10 MST & 13 MST & 16 MST \\
\hline C0P0 & $4,3333 \mathrm{a}$ & $11,333 \mathrm{ab}$ & $42,000 \mathrm{a}$ & $104,67 \mathrm{a}$ & $165,67 \mathrm{a}$ & $119,33 \mathrm{a}$ \\
\hline C0P1 & $3,6667 \mathrm{a}$ & $10,333 \mathrm{~b}$ & $35,000 \mathrm{a}$ & $82,33 \mathrm{a}$ & $141,00 \mathrm{a}$ & $130,00 \mathrm{a}$ \\
\hline C0P2 & $4,0000 \mathrm{a}$ & $9,667 \mathrm{~b}$ & $39,000 \mathrm{a}$ & $82,33 \mathrm{a}$ & $139,00 \mathrm{a}$ & $133,33 \mathrm{a}$ \\
\hline C0P3 & $4,3333 \mathrm{a}$ & $10,000 \mathrm{~b}$ & $33,333 \mathrm{a}$ & $92,67 \mathrm{a}$ & $140,00 \mathrm{a}$ & $133,00 \mathrm{a}$ \\
\hline C1P0 & $3,6667 \mathrm{a}$ & $10,667 \mathrm{~b}$ & $36,667 \mathrm{a}$ & $98,67 \mathrm{a}$ & $174,33 \mathrm{a}$ & $131,67 \mathrm{a}$ \\
\hline C1P1 & $4,3333 \mathrm{a}$ & $13,667 \mathrm{ab}$ & $37,667 \mathrm{a}$ & $93,67 \mathrm{a}$ & $174,00 \mathrm{a}$ & $142,33 \mathrm{a}$ \\
\hline C1P2 & $4,0000 \mathrm{a}$ & $11,000 \mathrm{ab}$ & $40,667 \mathrm{a}$ & $96,33 \mathrm{a}$ & $155,33 \mathrm{a}$ & $111,00 \mathrm{a}$ \\
\hline C1P3 & $4,3333 \mathrm{a}$ & $16,667 \mathrm{a}$ & $46,667 \mathrm{a}$ & $92,00 \mathrm{a}$ & $140,00 \mathrm{a}$ & $148,33 \mathrm{a}$ \\
\hline
\end{tabular}

Keterangan : Angka yang didampingi huruf yang sama pada kolom yang sama dan peubah yang sama tidak berbeda nyata pada uji DMRT taraf $5 \%$.

\subsection{Panjang Daun}

Hasil analisis ragam menunjukkan tidak terjadi interaksi yang nyata antara perlakuan varietas cabai dan media diapers. Hasil penelitian menunjukkan bahwa perlakuan varietas cabai merah dengan kombinasi $3 / 4$ media diapers $+1 / 4$ media tanah $\left(\mathrm{C}_{0} \mathrm{P}_{3}\right)$ menghasilkan panjang daun tanaman yang lebih tinggi dibandingkan dengan perlakuan varietas cabai rawit dengan tanpa kontrol atau kombinasi tanpa media pampers $\left(\mathrm{C}_{1} \mathrm{P}_{0}\right)$ dan kombinasi $1 / 4$ media diapers $+3 / 4$ media tanah $\left(\mathrm{C}_{1} \mathrm{P}_{1}\right)$. Perlakuan varietas cabai merah dengan kombinasi $1 / 4$ media diapers $+3 / 4$ media tanah $\left(\mathrm{C}_{0} \mathrm{P}_{1}\right)$ menghasilkan panjang daun tanaman yang lebih rendah.

Perlakuan varietas cabai tidak berpengaruh nyata terhadap panjang daun tanaman pada umur 1 MST tetapi berpengaruh nyata pada umur 4, 7, 10, 13 dan 16 MST. Perlakuan media diapers tidak berpengaruh nyata terhadap panjang daun tanaman pada umur $1,4,7,10,13$ dan 16 MST (Tabel 5). 
Tabel 5. Rerata Panjang Daun Tanaman (cm) Akibat Perlakuan Varietas Cabai dan Media Diapers.

\begin{tabular}{lllllll}
\hline \multirow{2}{*}{ Perlakuan } & \multicolumn{6}{l}{ Umur Tanaman (Minggu) } \\
\cline { 2 - 7 } 1 MST & 4 MST & 7 MST & 10 MST & 13 MST & 16 MST \\
\hline C0P0 & 2,8333 a & 4,2333 a & 4,7667 a & $5,0667 \mathrm{a}$ & $5,3000 \mathrm{ab}$ & $5,7667 \mathrm{a}$ \\
C0P1 & $2,5333 \mathrm{a}$ & $4,4000 \mathrm{a}$ & $4,6667 \mathrm{a}$ & $4,9333 \mathrm{a}$ & $5,2667 \mathrm{~b}$ & $5,4000 \mathrm{a}$ \\
C0P2 & $2,7667 \mathrm{a}$ & $4,5000 \mathrm{a}$ & $4,8667 \mathrm{a}$ & $5,2000 \mathrm{a}$ & $5,5667 \mathrm{ab}$ & $5,7667 \mathrm{a}$ \\
C0P3 & $3,0000 \mathrm{a}$ & $4,7667 \mathrm{a}$ & $5,1667 \mathrm{a}$ & $5,9333 \mathrm{a}$ & $6,3333 \mathrm{a}$ & $6,4667 \mathrm{a}$ \\
C1P0 & $2,6667 \mathrm{a}$ & $4,9667 \mathrm{a}$ & $5,4667 \mathrm{a}$ & $5,7000 \mathrm{a}$ & $6,0333 \mathrm{ab}$ & $6,1667 \mathrm{a}$ \\
C1P1 & $3,1667 \mathrm{a}$ & $4,8333 \mathrm{a}$ & $5,1333 \mathrm{a}$ & $5,4333 \mathrm{a}$ & $5,8667 \mathrm{ab}$ & $6,1667 \mathrm{a}$ \\
C1P2 & $2,7000 \mathrm{a}$ & $4,4333 \mathrm{a}$ & $5,0000 \mathrm{a}$ & $5,2000 \mathrm{a}$ & $5,7667 \mathrm{ab}$ & $5,9667 \mathrm{a}$ \\
C1P3 & $3,5000 \mathrm{a}$ & $4,8667 \mathrm{a}$ & $5,2667 \mathrm{a}$ & $5,6000 \mathrm{a}$ & $5,8667 \mathrm{ab}$ & $5,9333 \mathrm{a}$ \\
\hline
\end{tabular}

Keterangan :Angka yang didampingi huruf yang sama pada kolom yang sama dan peubah yang sama tidak berbeda nyata pada uji DMRT taraf $5 \%$.

Hasil analisis ragam menunjukkan tidak terjadi interaksi yang nyata antara perlakuan varietas cabai dan media diapers. Hasil penelitian menunjukkan bahwa perlakuan varietas cabai merah dengan kombinasi $3 / 4$ media diapers $+1 / 4$ media tanah $\left(\mathrm{C}_{0} \mathrm{P}_{3}\right)$ menghasilkan lebar daun tanaman yang lebih baik dibandingkan dengan perlakuan varietas cabai rawit dengan kombinasi $1 / 2$ media diapers $+1 / 2$ media tanah $\left(\mathrm{C}_{1} \mathrm{P}_{1}\right)$. Pada perlakuan varietas cabai merah dengan $1 / 4$ diapers
$+3 / 4$ media tanah $\left(\mathrm{C}_{0} \mathrm{P}_{1}\right)$ dan pelakuan varietas cabai rawit dengan kombinasi $1 / 4$ media diapers $+3 / 4$ media tanah $\left(\mathrm{C}_{1} \mathrm{P}_{1}\right)$ menghasilkan lebar daun yang rendah.

Perlakuan varietas cabai tidak berpengaruh nyata terhadap lebar daun tanaman padaumur 1, 4, 7, 10, 13 dan 16 MST. Perlakuan media diapers tidak berpengaruh nyata terhadap lebar daun tanaman pada umur 1, 4, 7, 10, 13 dan 16 MST (Tabel 6). 
Tabel 6. Rerata Lebar Daun Tanaman (cm) Akibat Perlakuan Varietas Cabai dan Media Diapers

\begin{tabular}{lcrrrrr}
\hline \multirow{2}{*}{ Perlakuan } & \multicolumn{6}{c}{ Umur Tanaman (Minggu) } \\
\cline { 2 - 7 } & 1 MST & 4 MST & 7 MST & 10 MST & 13 MST & 16 MST \\
\hline C0P0 & 0,6000 a & 1,4667 a & 2,0000 a & 2,3333 a & 2,5333 a & 2,7333 a \\
C0P1 & $0,6000 \mathrm{a}$ & 1,5667 a & 1,9333 a & 2,3000 a & 2,5667 a & 2,7667 a \\
C0P2 & 0,5000 a & 1,4667 a & 1,9000 a & 2,3333 a & 2,5333 a & 3,0333 a \\
C0P3 & 0,4667 a & 1,5000 a & 2,0000 a & 2,5000 a & $2 ., 8667$ a & 3,1667 a \\
C1P0 & 0,5000 a & 1,5667 a & 1,8333 a & 2,2667 a & 2,6667 a & 2,8000 a \\
C1P1 & 0,6333 a & 1,4000 a & 2,0000 a & 2,3667 a & 2,4000 a & 2,7667 a \\
C1P2 & 0,6667 a & 1,4667 a & 2,0000 a & 2,6000 a & 2,8667 a & 3,0333 a \\
C1P3 & 0,7667 a & 1,6333 a & 1.9333 a & 2,7333 a & 2,9667 a & 2,9333 a \\
\hline
\end{tabular}

Keterangan : Angka yang didampingi huruf yang sama pada kolom yang sama dan peubah yang sama tidak berbeda nyata pada uji DMRT taraf $5 \%$.

Pada jumlah cabang, hasil analisis ragam juga tidak berbeda nyata antara varietas cabai dan media diapers. Hasil penelitian menunjukkan bahwa perlakuan $\mathrm{C}_{1} \mathrm{P}_{3}$ menghasilkan jumlah cabang tanaman yang lebih tinggi dibandingkan dengan perlakuan varietas merah dengan kombinasi kontrol atau pada $\mathrm{C}_{1} \mathrm{P}_{2}$. Perlakuan varietas cabai merah dengan kombinasi $3 / 4$ media diapers $+1 / 4$ media tanah $\left(\mathrm{C}_{1} \mathrm{P}_{2}\right)$ menghasilkan jumlah cabang tanaman yang paling rendah.

Perlakuan varietas cabai tidak berpengaruh nyata terhadap jumlah cabang tanaman pada umur 1, 4, 7, 10,13 dan 16 MST. Perlakuan media diapers tidak berpengaruh nyata terhadap jumlah cabang tanaman pada umur 1, 4, 7, 10,13 dan 16 MST (Tabel 7).

Tabel 7. Rerata jumlah cabang (cm) Akibat Perlakuan Varietas Cabai dan Media Diapers.

\begin{tabular}{llllll}
\hline \multirow{2}{*}{ Perlakuan } & \multicolumn{6}{l}{ Umur Tanaman (Minggu) } \\
\cline { 2 - 6 } & 4 MST & 7 MST & $\mathbf{1 0}$ MST & $\mathbf{1 3 ~ M S T}$ & $\mathbf{1 6}$ MST \\
\hline C0P0 & $1,000 \mathrm{a}$ & $5,667 \mathrm{a}$ & $21,667 \mathrm{a}$ & $29,333 \mathrm{a}$ & $37,667 \mathrm{a}$ \\
C0P1 & $1,333 \mathrm{a}$ & $5,333 \mathrm{a}$ & $13,000 \mathrm{ab}$ & $23,000 \mathrm{a}$ & $32,333 \mathrm{a}$ \\
C0P2 & $1,333 \mathrm{a}$ & $4,667 \mathrm{a}$ & $13,000 \mathrm{ab}$ & $25,667 \mathrm{a}$ & $30,333 \mathrm{a}$ \\
C0P3 & $1,333 \mathrm{a}$ & $6,000 \mathrm{a}$ & $9,667 \mathrm{~b}$ & $22,000 \mathrm{a}$ & $29,667 \mathrm{a}$ \\
C1P0 & $1,667 \mathrm{a}$ & $4,333 \mathrm{a}$ & $14,333 \mathrm{ab}$ & $28,000 \mathrm{a}$ & $31,667 \mathrm{a}$ \\
C1P1 & $1,667 \mathrm{a}$ & $6,000 \mathrm{a}$ & $21,000 \mathrm{a}$ & $31,667 \mathrm{a}$ & $37,667 \mathrm{a}$ \\
C1P2 & $1,333 \mathrm{a}$ & $8,000 \mathrm{a}$ & $14,333 \mathrm{ab}$ & $30,333 \mathrm{a}$ & $30,333 \mathrm{a}$ \\
C1P3 & $1,667 \mathrm{a}$ & $8,333 \mathrm{a}$ & $19,000 \mathrm{ab}$ & $30,000 \mathrm{a}$ & $39,333 \mathrm{a}$ \\
\hline
\end{tabular}

Keterangan : Angka yang didampingi huruf yang sama pada kolom yang sama dan peubah yang sama tidak berbeda nyata pada uji DMRT taraf $5 \%$.

Secara statistik perlakuan media diapers tidak berpengaruh nyata terhadap jumlah cabang, namun kondisi tanaman yang diberikan media pampers dilihat secara fisik untuk tanaman terlihat sangat nyata. Pola hubungan jumlah cabang terhadap kondisi media pampers berdasarkan polinomial bersifat linier negatif pada fase vegetative. 
Pada perlakuan kontrol atau tanpa diapers $\left(\mathrm{P}_{0}\right)$ pertumbuhan jumlah cabang memberikan dampak yang positif. Hal ini dikarenakan kemampuan tanaman untuk menyerap unsur hara dan air sangat bagus dikarenakan tidak adanya keterbatasan akar dalam menyerap unsur hara. Jumlah cabang yang tertinggi terdapat pada varietas cabai rawit, hal ini ada hubungannya dengan tingkat kerusakan akar yang relatif rendah dan masih memungkinkan bagi tanaman untuk dapat tumbuh dan berkembang.

Percabangan pada tanaman cabai sangat penting sekali karena akan berpengaruh terhadap jumlah buah.
Menurut Setiawati (2005) bunga tanaman cabai tumbuh pada ujung percabangan. Artinya semakin banyak percabangan kemungkinan bunga yang terbentuk semakin banyak pula dan peluang pembentukan buah semakin banyak.

Hasil analisis ragam menunjukkan tidak terjadi interaksi yang nyata antara perlakuan varietas cabai dan media diapers. Perlakuan varietas cabai tidak berpengaruh nyata terhadap jumlah akar tanaman pada umur 4, 9 dan 14 MST. Perlakuan media diapers tidak berpengaruh nyata terhadap jumlah akar tanaman pada umur 4, 9 dan 14 MST (Tabel 8).

Tabel 8. Jumlah Akar Tanaman Cabai Akibat Perlakuan Varietas Cabai dan Media Diapers.

\begin{tabular}{llll}
\hline \multirow{2}{*}{ Perlakuan } & \multicolumn{3}{l}{ Umur Tanaman (Minggu) } \\
\cline { 2 - 4 } & 4 MST & 9 MST & 14 MST \\
\hline C0P1 & 68 & & \\
C1P0 & & 153 & 235 \\
C1P2 & & & \\
\hline
\end{tabular}

Hasil penelitian menunjukkan pada minggu ke- 4 mst tanaman cabai yang dibongkar yaitu varietas cabai merah dengan perlakuan kombinasi $1 / 4$ media diapers $+3 / 4$ media tanah $\left(\mathrm{C}_{0} \mathrm{P}_{1}\right)$ dengan jumlah 68 akar. Sedangkan pada minggu ke- 9 tanaman cabai yang dibongkar adalah varietas cabai merah dengan perlakuan kombinasi tanpa kontrol atau tanpa diapers $\left(\mathrm{C}_{0} \mathrm{P}_{0}\right)$ dengan jumlah 153 akar. Dan sedangkan pada minggu ke- 14 tanaman cabai yang dibongkar adalah varietas cabai rawit dengan perlakukan kombinasi tanpa kontrol atau tanpa media diapers $\left(\mathrm{C}_{1} \mathrm{P}_{0}\right)$ dengan jumlah 235 akar.

Hasil analisis ragam menunjukkan tidak terjadi interaksi yang nyata antara perlakuan varietas cabai dan media diapers. Perlakuan varietas cabai tidak berpengaruh nyata terhadap jumlah cabang tanaman pada umur 4, 9 dan 14 MST. Perlakuan media diapers tidak berpengaruh nyata terhadap jumlah cabang tanaman pada umur 4, 9 dan 14 MST (Tabel 9). 
Tabel 9. Panjang Akar Tanaman (cm) Akibat Perlakuan Varietas Cabai dan Media Diapers.

\begin{tabular}{llll}
\hline \multirow{2}{*}{ Perlakuan } & \multicolumn{3}{l}{ Umur Tanaman (Minggu) } \\
\cline { 2 - 4 } & 4 MST & 9 MST & 14 MST \\
\hline C0P1 & 4,5 & & \\
C1P0 & & 8 & 11,5 \\
C1P2 & & & \\
\hline
\end{tabular}

Hasil penelitian menunjukkan pada minggu ke- 4 mst tanaman cabai yang dibongkar yaitu varietas cabai merah dengan perlakuan kombinasi $1 / 4$ media diapers $+3 / 4$ media tanah $\left(\mathrm{C}_{0} \mathrm{P}_{1}\right)$ dengan panjang akar $4,5 \mathrm{~cm}$. Sedangkan pada minggu ke- 9 tanaman cabai yang dibongkar adalah varietas cabai merah dengan perlakuan kombinasi tanpa kontrol atau tanpa media diapers $\left(\mathrm{C}_{0} \mathrm{P}_{0}\right)$ dengan panjang akar $8 \mathrm{~cm}$. Dan sedangkan pada minggu ke- 14 tanaman cabai yang dibongkar adalah varietas cabai rawit dengan perlakukan kombinasi tanpa kontrol atau tanpa media diapers $\left(\mathrm{C}_{1} \mathrm{P}_{2}\right)$ dengan panjang akar $11,5 \mathrm{~cm}$.

Hasil analisis ragam menunjukkan tidak terjadi interaksi yang nyata antara perlakuan varietas cabai dan media diapers. Perlakuan varietas cabai tidak berpengaruh nyata terhadap umur berbunga tanaman pada umur 4, 5 dan 8 MST. Perlakuan media diapers tidak berpengaruh nyata terhadap jumlah cabang tanaman pada umur 4, 9 dan 14 MST (Tabel 10).
Tabel 10.Umur berbunga Tanaman (hari) Akibat Perlakuan Varietas Cabai dan Media Diapers.

\begin{tabular}{ll}
\hline Perlakuan & Umur Tanaman (Minggu) \\
\hline C0P0 & $45,667 \mathrm{a}$ \\
\hline C0P1 & $35,667 \mathrm{ab}$ \\
\hline C0P2 & $35,667 \mathrm{a}$ \\
\hline C0P3 & $43,333 \mathrm{ab}$ \\
\hline C1P0 & $30,333 \mathrm{ab}$ \\
\hline C1P1 & $30,333 \mathrm{ab}$ \\
\hline C1P2 & $29,333 \mathrm{~b}$ \\
\hline C1P3 & $28,333 \mathrm{~b}$
\end{tabular}

Keterangan :Angka yang didampingi huruf yang sama pada kolom yang sama dan peubah yang sama tidak berbeda nyata pada uji DMRT taraf 5 $\%$.

Hasil penelitian menunjukkan bahwa perlakuan varietas cabai merah dengan perlakuan kombinasi $3 / 4$ media diapers $+1 / 4$ media tanah $\left(\mathrm{C}_{0} \mathrm{P}_{3}\right)$ menghasilkan umur berbunga yang lebih cepat dibandingkan dengan perlakuan varietas cabai merah dengan perlakuan kombinasi $1 / 2$ media diapers $+1 / 2$ media tanah $\left(\mathrm{C}_{1} \mathrm{P}_{2}\right)$. Perlakuan varietas cabai merah dengan perlakuan kombinasi tanpa kontrol atau tanpa media diapers $\left(\mathrm{C}_{0} \mathrm{P}_{0}\right)$ menunjukkan umur berbunga yang rendah.

Perlakuan varietas cabai merah dengan kombinasi tanpa kontrol atau tanpa media diapers diapers $\left(\mathrm{C}_{1} \mathrm{P}_{2}\right)$ memperlihatkan umur berbunga berpengaruh tidak nyata, hal ini disebabkan karena muncul bunga pada 
suatu tanaman dipengaruhi oleh sifat genetik dan lingkungan. Umur muncul bunga $75 \%$ pada penelitian ini dibandingkan dengan deskripsi umur berbunga pada tanaman cabai merah tidak jauh berbeda pada deskripsi umur berbunga adalah 25-30 hari setelah tanaman.

Salah satu faktor lingkungan yang mempengaruhi umur muncul bunga adalah ketinggian tempat dari permukaan laut (altitude), terutama berkaitan dengan suhu udara dan intensitas sinar yang diterima oleh tanaman. Semakin tinggi suatu tempat, semakin rendah suhu tempat tersebut, demikian juga intensitas matahari semakin berkurang. Muawin (2009) menyatakan bahwa suhu berpengaruh terhadap pertumbuhan vegetatif, induksi bunga, pertumbuhan dan differensiasi perbungaan (inflorescence), mekar bunga, munculnya serbuk sari, pembentukan benih danpemasakan benih.

Hasil analisis ragam menunjukkan tidak terjadi interaksi yang nyata antara perlakuan varietas cabai dan media diapers. Perlakuan varietas cabai tidak berpengaruh nyata terhadap berat basah akar dan tajuk tanaman pada umur 4, 9 dan 14 MST. Perlakuan media diapers tidak berpengaruh nyata terhadap berat basah akar dan tajuk tanaman pada umur 4, 9 dan 14 MST (Tabel 11).

Hasil penelitian menunjukkan pada minggu ke- 4 mst tanaman cabai yang dibongkar yaitu varietas cabai merah dengan perlakuan kombinasi $1 / 4$ media diapers $+3 / 4$ media tanah $\left(\mathrm{C}_{1} \mathrm{P}_{2}\right)$ dengan berat basah akar dan tajuk tanaman 2,13 gr. Sedangkan pada minggu ke- 9 tanaman cabai yang dibongkar adalah varietas cabai merah dengan perlakuan kombinasi tanpa kontrol atau tanpa media diapers $\left(\mathrm{C}_{0} \mathrm{P}_{0}\right)$ dengan berat basah akar dan tajuk tanaman 6,86 gr. Dan sedangkan pada minggu ke- 14 tanaman cabai yang dibongkar adalah varietas cabai rawit dengan perlakukan tanpa kontrol atau tanpa diapers $\left(\mathrm{C}_{1} \mathrm{P}_{0}\right)$ dengan berat basah akar dan tajuk tanaman 33,62 gr.

Tabel 11.Berat Basah Akar Dan Tajuk Tanaman (gr) Akibat Perlakuan Varietas Cabai dan Media Diapers.

\begin{tabular}{llcl}
\hline \multirow{2}{*}{ Perlakuan } & \multicolumn{3}{l}{ Umur Tanaman (Minggu) } \\
\cline { 2 - 4 } & 4 MST & 9 MST & 14 MST \\
\hline C0P1 & 2,13 & & \\
C1P0 & & 6,86 & 33,62 \\
C1P2 & & & \\
\hline
\end{tabular}

Tabel 12.Berat Kering Akar Dan Tajuk Tanaman (gr) Akibat Perlakuan Varietas Cabai dan Media Diapers.

\begin{tabular}{llcl}
\hline \multirow{2}{*}{ Perlakuan } & \multicolumn{4}{l}{ mur Tanaman $($ Minggu) } \\
\cline { 2 - 4 } & 4 MST & 9 MST & 14 MST \\
\hline C0P1 & 0,51 & 1,24 & \\
C1P0 & & & 7,07 \\
C1P2 & & & \\
\hline
\end{tabular}


Hasil penelitian menunjukkan pada minggu ke- 4 mst tanaman cabai yang dibongkar yaitu varietas cabai merah dengan perlakuan kombinasi $1 / 4$ media diapers $+3 / 4$ media tanah $\left(\mathrm{C}_{0} \mathrm{P}_{1}\right)$ dengan berat basah akar dan tajuk tanaman 0,51 gr. Sedangkan pada minggu ke- 9 tanaman cabai yang dibongkar adalah varietas cabai merah dengan perlakuan kombinasi tanpa kontrol atau tanpa media diapers $\left(\mathrm{C}_{0} \mathrm{P}_{0}\right)$ dengan berat basah akar dan tajuk tanaman 1,24 gr. Dan sedangkan pada minggu ke- 14 tanaman cabai yang dibongkar adalah varietas cabai rawit dengan perlakukan kombinasi tanpa kontrol atau tanpa media diapers $\left(\mathrm{C}_{1} \mathrm{P}_{0}\right)$ dengan berat basah akar dan tajuk tanaman 7,07 gr.

\section{DAFTAR PUSTAKA}

Badan pusat statistik (BPS). 2012. Produksi Cabai Besar, Bawang Merah, Dan Mangga Tahun 2011. Jakarta : Biro Pusat Statistik.

Campbell, R. L., Seymour, J. L. Stone, L.C., Milligan, M. C. 2007. Clinical Studies Disposable Diapers Containing Gelling Material : Evaluation On Effect On Infant Skin Condition. Journal Of The American Academiy Of Dermatology.Volume17, Issue 6, Desember 1987 Pages 978-987.
Muawin, Heru. 2009. Hubungan Suhu Bagi Pertumbuhan Tanaman. http:///herumuawin.blogspot.co m/2009/03hubungan-suhubagipertumbuhan-tanaman. di Akses pada 1 Desember 2016.

Michael J. Devito. Arnold Schester. Exposure Assasement To Dioxin From Use Tampon And Diapers. Enviromental Health Perspectives. Volume 110 Number 1 Januari 2002 23-28. Page 2.

Poerwanto, R. Dan A. D. Susila. 2014. Hortikultura Tropika, Buku I: Teknologi Hortikultura. Ipb Press, Bogor. 338.

Rukmana, R, 2003. Bertanam Cabai Rawit. Penerbit Kanisius. Yogjakarta.

Safrizal, 2007. Status hara nitrogen, phosfot, dan kalium pada tanaman manggis tahun produksi ketiga. Thesis. Institut Pertanian Bogor. 186 hal.

Tjahjadi, 2004. Bertanam Cabai Merah. Penerbit Kanisius. Yogyakarta.

Wuryaningsih, S. 2008. Media Tanam Tanaman Cabai. Jurnal Penelitian Pertanian 19 (1): 32 S/D 38. 